\title{
A New Cardioselective $\beta$-Adrenoceptor Blocking Agent
}

During the last few years we have sought $\beta$-adrenoceptor blocking agents with cardioselective properties which would be of value clinically in the management of angina pectoris and cardiac arrhythmias whilst having a low tendency to increase bronchospasm and contributing to the control of arrhythmia. We first examined the possibility of conferring selectivity on conventional $\beta$-blocking agents by incorporating the usual hydroxyisopropyl-ami- properties and in increasing the refractory period of isolated rabbit atria. $\mathrm{M} \& \mathrm{~B} 17803 \mathrm{~A}$ is an active $\beta$-adrenoceptor blocking agent in man ${ }^{6,7}$.

Full reports of the chemistry and pharmacology of this compound and its analogues will be presented later.

Zusammentassung. Es wird die Synthese des cardiospezifisch $\beta$-adrenozeptorblockierenden (RS-1-(2-acetyl-<smiles>c1ccc2c(c1)OC1CCNCC1O2</smiles><smiles>OC1CNc2ccccc2OC1</smiles>

2<smiles>[Y6]C1=NCC(O)COc2ccccc21</smiles>

3<smiles>[R]C(=NO)c1cc([R])ccc1OCCOCCNC(C)C</smiles>

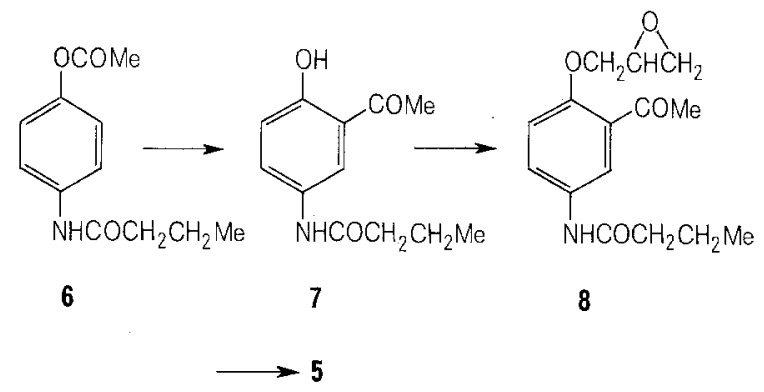

no-propoxy side-chain into heterocyclic systems such as hexahydropyrido-benzodioxans $1{ }^{1}$ benzoxazepines $2^{2}$ or benzoxazocines $3^{3}$. Extension of this work led us to prepare a series of oximes of general structure 4 in which vascular or cardiac specificity could be enhanced by appropriate substituents. We now wish to report that a ketone derived from this series, RS-1-(2-acetyl-4-n-butyramidophenoxy)-2-hydroxy-3-isopropylaminopropane hydrochloride 5 (M\&B 17803A), possesses marked cardioselective $\beta$-adrenoceptor blocking properties.

The compound has been prepared by the following route. Fries rearrangement of 4 -n-butyramidophenyl acetate $\mathbf{6}$ to 2-acetyl-4-n-butyramidophenol 7 followed by treatment with epichlorhydrin afforded the epoxide 8. Treatment with isopropylamine gave RS-1-(2-acetyl-4n-butyramidophenoxy) - 2-hydroxy-3-isopropylaminopropane, m.p. $129-130^{\circ}$. The hydrochloride, M \&B 17803A,

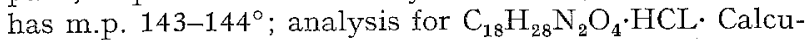
lated: C, $58.0 ; \mathrm{H}, 7.8 ; \mathrm{N}, 7.5$ : Found: C, 57.9; H, 7.9; $\mathrm{N}, 7.2 \%, \gamma_{\max }^{\mathrm{EtOH}} 236 \mathrm{~nm}(\log =4.39), 332 \mathrm{~nm}(\log =3.40)$.

Pharmacological studies in experimental animals ${ }^{4,5}$ indicate that $\mathrm{M} \& \mathrm{~B} 17803 \mathrm{~A}$ is a cardioselective $\beta$-adrenoceptor blocking agent with potency comparable to that of practolol. It differs from the latter drug and resembles propranolol in possessing significant local anaesthetic 4-n-butyramidophenoxy)-2-oxy-3-isopropylaminopropan hydrochlorids beschrieben.

K.R.H. WOOLDRIDGE

Research Laboratories, May \& Baker Lid., Dagenham, Essex, RM10 7XS (England), 19 June 1972.

1 C. J. Coulson and K. R. H. Wooldridge, J. chem. Soc. (C) 1969 , 2830.

2 C. J. Coulson, J. Memel, B. J. Millard and K. R. H. WooldRIDGE, J. chem. Soc. (C) 1970, 1164.

3 B. Basil, E. C. J. Coffee, D. L. Geil, D. R. Maxwell, D. J. ShEFFIELD and K. R. H. Wooldridge, J. med. Chem. 13, 403 (1970).

4 B. Basil, R. Jordan, A. H. Loveless and D. R. Maxwell, J. Pharm., Paris 2, 195 (1971).

- B. Basil, R. Jordan, A. H. Loveless and D. R. Maxwell, Br. J. Pharmac., in press.

6 M. F. Cuthbert, K. Owusu-Angomar, Br. J. Pharmac. 43, 639 (1971).

7 R. H. Briant, C. T. Dollery, T. Fenyuesi and C. F. George, Br. J. Pharmac., 43, 468P (1971). 